\title{
Penicillin resistant pneumococcal peritonitis in nephrotic syndrome
}

\author{
L S MILNER, F E BERKOWITZ, E NGWENYA, U KALA, AND D JACOBS
}

Department of Paediatrics, University of Witwatersrand, and Baragwanath Hospital, Johannesburg, South Africa

\begin{abstract}
SUMMARY Two infants with nephrotic syndrome who developed penicillin resistant pneumococcal peritonitis while receiving penicillin chemoprophylaxis are reported and the problems associated with prophylaxis against pneumococcal infection discussed. It is suggested that penicillin prophylaxis may be hazardous in an environment in which penicillin resistant pneumococci are prevalent.
\end{abstract}

Children with nephrotic syndrome are at an increased risk of developing peritonitis due to Streptococcus pneumoniae. The depressed immune state caused by the nephrotic syndrome is due to decreased serum concentrations of immunoglobulins ${ }^{1}$ and impaired opsonisation, ${ }^{2}$ cellular immunity, ${ }^{3}$ and granulocyte chemotaxis. ${ }^{2}$ Prophylaxis against pneumococcal infection may be attempted with pneumococcal polysaccharide vaccine or with oral penicillin. We report two children with nephrotic syndrome who developed penicillin resistant pneumococcal peritonitis while receiving prophylaxis with oral penicillin. S penumoniae was identified as an $\alpha$-haemolytic streptococcus sensitive to optochin. Antibiotic sensitivity testing of this organism was performed on $5 \%$ sheep blood agar by the Kirby-Bauer disc diffusion method. Penicillin resistance was defined by a zone of inhibition smaller than $20 \mathrm{~mm}$ around a $5 \mu \mathrm{g}$ methicillin disc.

\section{Case reports}

\section{CASE 1}

A 2 month old black boy with histologically confirmed Finnish type congenital nephrotic syndrome was given oral prophylaxis with phenoxymethyl penicillin (62.5 mg twice daily) and co-trimoxazole $(2 \mathrm{mg} / \mathrm{kg}$ daily of trimethoprim). One week after discharge he was readmitted with vomiting and abdominal distension. Examination showed that his systolic blood pressure was $40 \mathrm{~mm} \mathrm{Hg}$ and pulse rate was 120 /minute. He had poor peripheral perfusion and generalised oedema. Abdominal examination showed ascites, and the liver and spleen edges were palpable $2.5 \mathrm{~cm}$ and $1 \mathrm{~cm}$, respectively, below the right and left costal margins. The heart was normal and the lung fields were dull to percussion at both bases. There was neck retraction, a bulging anterior fontanelle, and hypertonia.

Laboratory investigations showed a haemoglobin concentration of $7 \cdot 7 \mathrm{~g} / \mathrm{dl}$, a white cell count of $8 \cdot 2 \times$ $10^{9} / \mathrm{l}$, and a platelet count $412 \times 10^{9} / \mathrm{l}$; serum urea concentration was $17.8 \mathrm{mmol} / \mathrm{l}$, sodium concentration $137 \mathrm{mmol} / \mathrm{l}$, potassium concentration 4.0 $\mathrm{mmol} / \mathrm{l}$, chloride concentration $99 \mathrm{mmol} / \mathrm{l}$, and creatinine concentration $145 \mu \mathrm{mol} / \mathrm{l}$ (normal for age, $30-55 \mu \mathrm{mol} / \mathrm{l}$ ). Examination of the cerebrospinal fluid was normal. $S$ pneumoniae resistant to penicillin was cultured from the peritoneal fluid. $\mathrm{He}$ was treated with intravenous fluid replacement and albumin together with frusemide and cefotaxime. He died two days after admission.

CASE 2

A 2 day old black girl was admitted after a generalised seizure. She was the product of an uneventful pregnancy and delivery. On examination her rectal temperature was $34.8^{\circ} \mathrm{C}$, she had sclerema of the limbs, and Kussmaul's respiration. The pulses were all present, with a rate of $160 /$ minute. The heart and lungs were normal on auscultation. On abdominal examination the liver edge was palpable $4 \mathrm{~cm}$ below the right costal margin. The child had generalised hypertonia and a tense fontanelle.

Laboratory investigations showed a haemoglobin concentration of $14.2 \mathrm{~g} / \mathrm{dl}$, a white cell count of 7.9 $\times 10^{9} / 1$, and a platelet count of $125 \times 10^{9} / 1$. Her serum sodium concentration was $126 \mathrm{mmol} / \mathrm{l}$, potassium concentration $7.5 \mathrm{mmol} / \mathrm{l}$, chloride concentration $98 \mathrm{mmol} / \mathrm{l}$, bicarbonate concentration $12 \cdot 3$ $\mathrm{mmol} / \mathrm{l}$, urea concentration $22.9 \mathrm{mmol} / \mathrm{l}$, and creatinine concentration $268 \mu \mathrm{mol} / \mathrm{l}$ (normal for age, $60-75 \mu \mathrm{mol} / 1)$. Analysis of urine by dipstick showed a $\mathrm{pH}$ of 5 , moderate proteinuria, and haematuria. The fractional excretion of sodium on admission was $0 \cdot 34 \%$, suggesting hypovolaemia. Treatment was started with intravenous fluid replacement and sodium bicarbonate, together with penicillin and cefotaxime. She subsequently improved but became progressively more oedematous and developed ascites. The serum albumin concentration decreased from $19.1 \mathrm{~g} / \mathrm{l}$ on admission to $8 \mathrm{~g} / \mathrm{l}$, with severe proteinuria on testing of the urine. The serum cholesterol concentration was $5.2 \mathrm{mmol} / \mathrm{l}$ (normal 
for age $1.8-4.5 \mathrm{mmol} / \mathrm{l})$ and triglyceride concentration $1.48 \mathrm{mmol} / \mathrm{l}$ (normal for age $0.37-1.2 \mathrm{mmol} / \mathrm{l}$ ). The nephrotic syndrome was diagnosed and studies to determine the aetiology were planned. The antimicrobial treatment was changed to phenoxymethyl penicillin (62.5 mg twice daily) and cotrimoxazole $(2 \mathrm{mg} / \mathrm{kg}$ daily of trimethoprim). Two weeks later she developed tense ascites, pallor, and hypothermia. Culture of the peritoneal fluid showed $S$ pneumoniae resistant to penicillin. She improved on treatment with intravenous vancomycin.

\section{Discussion}

Patients with the nephrotic syndrome are at an increased risk of developing systemic pneumococcal infections due to perturbations of the normal immune responses. ${ }^{1-3}$ Immunisation with pneumococcal polysaccharide vaccine seems to be the most rational method of preventing pneumococcal disease, but it may not be effective in children younger than 2 years, ${ }^{4}$ or protective in patients with nephrotic syndrome who are resistant to steroid treatment. ${ }^{5}$ For these reasons we have used penicillin prophylaxis in nephrotic children younger than 2 years of age which has the potential disadvantage of encouraging the emergence of penicillin resistant pneumococci.

In a recent survey at this hospital $24 \%$ of pneumococcal isolates from blood culture in children were due to penicillin resistant strains that were both hospital and community acquired. ${ }^{6} \mathrm{We}$ believe that the two patients reported here became colonised in the nasopharynx with penicillin resistant pneumococci while they were in hospital, and that the use of prophylactic penicillin selected for penicillin resistant strains subsequently resulted in invasive disease. Our experience suggests that this practice may be hazardous in a hospital or community in which penicillin resistant pneumococci are common. Our current practice is to give pneumococcal vaccination to nephrotic children at 2 years of age. For younger children we no longer give antimicrobial prophylaxis but explain the potential risks of infection to the parents who are advised to seek urgent medical attention for any febrile illness. Further studies are planned to evaluate the role of antimicrobial prophylaxis in preventing pneumococcal infection in nephrotic syndrome.

\section{References}

' Giangiacomo J, Cleary TG, Cole B, et al. Serum immunoglobulins in the nephrotic syndrome. $N$ Engl J Med 1975;293:8-12.

2 Anderson DC, York TL, Rose G, Smith GC. Assessment of serum factor B, serum opsonins, granulocyte chemotaxis and infection in nephrotic syndrome of children. $J$ Infect Dis 1979;140:1-11.

3 Smith MD, Barratt TM, Hayward AR, et al. The inhibition of complement dependent lymphocyte rosette formation by the sera of children with steroid-sensitive nephrotic syndrome and other renal diseases. Clin Exp Immunol 1975;21:236-43.

4 Committec on Infectious Discases, American Academy of Pediatrics Recommendations for using pneumococcal vaccine in children. Pediatrics 1985;75:1153-8.

5 Spika SJ, Halsey NA, Fisher AJ, et al. Scrum antibody response to pneumococcal vaccine in children with nephrotic syndrome. Pediatrics 1982;69:219-23.

6 Berkowitz FE. Bacteremia in hospitalized black South African children. A one year study emphasizing nosocomial bacteremia and bacteremia in severely malnourished children. Am J Dis Child 1984;138:551-6.

Correspondence to Dr L Milner, Department of Pacdiatrics, Johannesburg Hospital, Parktown, Johannesburg, South Africa.

Received 3 April 1987

\section{Infant feeding and atopy}

\section{R E MIDWINTER, A F MORRIS, AND J R T COLLEY}

\section{Department of Epidemiology and Community Medicine, University of Bristol}

SUMmary Parents of 4575 year olds from a previous study of infant feeding and eczema in the first year of life were questioned about subsequent atopy. No association was found with early breast or bottle feeding. Family history was important. Parental recall of first year eczema was often inaccurate.

Between 1979 and 1981 we studied the association between different types of infant feeding and eczema. ${ }^{1}$ Four hundred and seventy five infants born to parents with a family history of atopy were investigated to see if there was an association between feeding in the first weeks of life and the incidence of eczema during the first year. Exclusive breast feeding in the first four weeks postponed the onset of eczema; significantly fewer infants had eczema at three and six months, but by one year the incidence was similar in breast and bottle fed infants. To investigate a possible association with 